\title{
GENDERIZING CONSEQUENCES OF FAMILY POLICIES IN POLAND IN 2010S: A SOCIOLOGICAL PERSPECTIVE
}

\author{
KATARZYNA SUWADA ${ }^{1}$ \\ ${ }^{1}$ Nicolaus Copernicus University in Toruń, Fosa Staromiejska 1a, 87-100 Toruń, Poland. ORCID: \\ 0000-0001-8785-855X, Email: k.suwada@umk.pl
}

\begin{abstract}
The aim of this paper is to analyze four reforms introduced in the Polish family system in the 2010s. The reforms were introduced as an answer to a problem of very low fertility rates, as well as instruments helping women in achieving their worklife balance. The reforms are analyzed here in terms of their (de)genderization effects on Polish mothers and fathers. The use of a genderization-degenderization axis shows that the gendered division of domestic and care work is not challenged by the reforms, but it is rather reinforced by them. It is also doubtful if the reforms will manage to reverse current demographic trends.

KEYWORDS: Family policy, genderization, gender inequalities, Poland, parental leaves, childcare
\end{abstract}

\section{INTRODUCTION}

Since the collapse of communism East-Central Europe has been facing decreasing fertility rates and is now experiencing a serious demographic crisis. The burning question is how to design a family policy system to provide people with good conditions for having more than one child. This is also the question that policymakers in Poland have been trying to answer since the 2000s. The fertility rates in Poland are at an extremely low level, 1.22 in 2003, 1.40 in 2009, and since 2013 they remain at the 
level around 1.3. Poles are not deciding to have more than one child, even though in surveys they declare that they would like to (see: Mynarska 2011). The literature on family studies indicates different reasons for low fertility rates in European societies. One reason concerns gender equality. Studies show that in countries with greater gender equality where men have greater involvement in care work, people are more eager to continue childbearing (Andersson, Duvander, and Hank 2004; Duvander and Andersson 2006). At the same time, Polish researchers point out the so-called women's reproductive strike, which should be understood as women's decision not to have children, even against their own willingness to have them (Graff 2014; Korolczuk and Hryciuk 2012). This reproductive strike results from the burden of combining motherhood and care work with paid work and a general withdrawal of Polish men from the domestic sphere. Polish women are overloaded with unpaid work in the household and paid work in the labor market (Suwada 2021). Yet policymakers do not recognize this as a problem.

The aim of this paper is to analyze the reforms introduced in Polish family systems since 2010 through the lenses of the genderization concept proposed by Steven Saxonberg and by incorporating the perspective of Polish parents. ${ }^{1}$ Since 1989 Polish family policy has been characterized by the lack of a coherent and long-term strategy. Up until the 2010s there was a lack of reflection on work-life balance issues and gender inequalities, even though some elements of gender mainstreaming policy started to be implemented in connection with membership of the EU (Scambor et al. 2014). Only at the beginning of the 2010s did Polish policymakers begin to slowly recognize the problem of low fertility rates and to reform the family policy system that had been practically untouched since the 1970s. I concentrate here on four reforms which have been introduced since 2010, which substantially changed the family policy system in Poland.

The article begins with a discussion of the links between family policy instruments and gender roles. I refer here to the new welfare typology proposed by Saxonberg (2013, 2014) based on the genderization-degenderization axis. Then I proceed to a description of the reforms in terms of their aims and objectives, as well as the effects they have on gender equality and gender roles, especially within the family sphere. I depict the reforms separately, since they were not introduced as a part of one coherent program, but rather were unrelated. The article concludes with a discussion of the overall effect of the analyzed reforms and its impact on gender inequalities.

\section{(DE)GENDERIZING CONSEQUENCES OF FAMILY POLICY}

Different family policy instruments differently affect fertility rates, organization of families' everyday life, as well as the gender division of domestic and care work. Various classifications of welfare states try to cluster them into different types of regimes.

\footnotetext{
${ }^{1}$ Because of the lack of place in the article I concentrate on the institutional settings, therefore I do not discuss a wider socio-cultural context, as well as socio-economic inequalities, that can also explain differences between the engagement of men and women in parenthood in Polish society. These issues are discussed in other publications on parenthood in Poland, see: Suwada 2017 and 2021.
} 
Two the most common contemporary classifications analyze family policies in terms of it (de)familialization and (de)genderization effects (Kurowska 2018). Since my aim here is to analyze the effect of family policy reforms on gender roles, I refer here mainly to the (de)genderization approach, even though Kurowska claims they should not be treated as competing theoretical perspectives, but rather as complementary ones. This approach was proposed by Steven Saxonberg (2013, 2014), whose aim was to create a typology of welfare state policies that include the gender dimension of social reality. Family policies are analyzed in terms of their impact on gender roles that are understood here as particular expectations towards men and women that tell how they should act in different social situations (see Ridgeway \& Correll 2004). As Saxonberg emphasizes, today the desire to eliminate gender roles has become an official EU policy, which focuses more on the equal sharing of paid and unpaid work rather than on equal treatment (Saxonberg 2013: 32). In this context we can distinguish genderizing and degenderizing policies. Genderizing policies promote different gender roles for men and women, whereas degenderizing policies fight against gender roles and bolster their elimination. There are two types of genderizing policies. The first type explicitly supports different gender roles by, for example, encouraging only women to leave the labor market in connection to parenthood. Whereas the second type implicitly upholds existing gender inequalities because of their patriarchal starting point.

In Saxonberg typology the focus is put on actual policies and their effects on individuals, rather than overall regime types within which different policies are implemented. Such an approach allows for a detailed analysis of various policies existing within one system and a clear focus on the problem of gender inequalities, which is often regarded as crucial in the context of fertility rates and reproductive decisions of Europeans. Saxonberg focuses on the two most important policies of the family system that influence gender roles: the paid parental leave system and state support for childcare. The parental leave system is degenderizing when parental leave is long enough to share between a mother and a father, the replacement rate is high enough to allow men to use the parental leave system without major financial loss to the whole family, the benefit ceiling is not too low, and there exists a quota for fathers. In an explicitly genderizing system leave is mostly a woman's right. Women have a right to highly paid leave for at least fifteen weeks. For fathers, if at all, there is only a short paternity leave that can be used to help a mother after childbirth. Additionally, both parents have a right to a long extended parental leave with a low flat-rate benefit, which usually discourages men from taking the leave. In an implicitly genderizing system there is usually no paid leave or only a short maternity leave.

Degenderizing childcare institutions are characterized by either the provision of a large number of places for all children in public institutions, or highly subsidized places in private institutions. An explicitly genderizing system provides some support for childcare, but mostly for children over three, and most likely only part-time. In an implicitly genderizing system, childcare institutions are private and operate on the free market, there are low public subsidies and a relatively small number of places for children under three.

The following analysis also takes account of child benefit instruments. Saxonberg 
does not interpret child benefits in terms of their (de)genderizing effect, yet he claims that such interpretations are possible. Since child benefit policies significantly vary across welfare states, it is difficult to assess their general (de)genderizing effects. They also have various aims - universal benefits are usually regarded either as financial support for a family or as an incentive for people to have more children. Means-tested benefits are rather seen as an instrument preventing poverty among children. It can be cautiously assumed that high universal benefit might have genderizing consequences, since it might encourage women to stay home and take care of children. Whereas low universal benefits do not have such an effect, although it is impossible to classify them as degenderizing as well. In the case of means-tested benefits the genderizing consequences can only be observed among women with lower incomes. Yet to fully assess the impact of cash benefits for women, the broader social context should be taken into consideration - such as access to childcare institutions, cultural norms about care, the gender wage gap, and the situation of men and women in the labor market.

As Saxonberg underlines, there should be a clear dividing line between policies and their actual outcomes. Thus in my analysis, firstly I depict the policies and their goals, and then proceed to the outcomes. As will become clear, the aims and outcomes of analyzed policies are not always congruent. In fact, in many cases the actual outcomes are divergent from those which were anticipated.

\section{METHODS}

The presented analysis is based on data from multiple sources. First, analysis of government documents containing justifications for the reforms which they had introduced. Justifications for the reforms are published on the website of the responsible ministries together with corresponding acts. The analysis focused on four documents: the justifications introducing paternity leave from 2008, parental leave from 2013, the justifications for the "Toddler" program from 2011 and the "Family 500+" program from 2016. Additionally the speech of the Ministry of Family, Labor and Social Policy Elżbieta Rachwalska during the first reading of the government's draft law on the "Family 500+" Program from February 9, 2016 was . In the qualitative analysis conducted in MaxQDA the main goals and objectives set by policymakers were identified. These goals and objectives are strongly linked with a preferable organization of family life, in this case based on traditional gender roles. The documents were collected from the official websites of the Ministry of Labor and Social Policy (since 2015 the Ministry of Family, Labor and Social Policy) and of the Polish Parliament.

Secondly, I refer to the national statistics gathered by the Statistics Poland and the Social Insurance Institution. The statistics about the use of parental leaves and the enrolment of children to care institutions show how much the introduced reforms changed the situation of Polish parents. Finally, the analysis is based on data from qualitative interviews conducted with Polish parents in two research projects. The first project was conducted 2012-2013 and concentrated on the fatherhood experiences of Polish men. The second project was conducted in the summer of 2017 and interviews focused on the problem of the work-life balance. In both cases the issue of 
family policy instruments was often mentioned and discussed by interviewees. Their experiences and reflections shed light on how the introduced reforms affect the everyday life of Polish families.

In the first project forty-six interviews were conducted with middle class parents living in large Polish cities. The interviews concentrated on the fatherhood experiences of heterosexual and coupled fathers who lived with their children. In the second project there were fifty-three interviews carried out with parents who had different social and economic backgrounds (lower class, middle class, and upper middle class), parents in different family situations (coupled parents, single parents, divorced parents, and reconstituted families), and parents living in different locations (countryside, small, medium, and large cities). The interviews concentrated on the dynamics of work-life experiences, and also on the strategies adopted by men and women in connection to parenthood. All interviews from both projects were transcribed in confidentiality and analyzed in qualitative research software (MaxQDA). The interviews from the first project were analyzed a second time in 2017 in terms of family policy instruments. The analysis was conducted using a mixed strategy of open and thematic coding (Ayres 2008; Benaquisto 2008). Captions after the citations show the gender of the interviewee, age of child/children, and the year in which the interview was conducted.

Analyzing the family policy system using a triangulation strategy, i.e. using data from different sources (Rothbauer 2008), provides an opportunity to draw relevant conclusions, in which not only policymakers' aims are articulated, but also the actual effects of the introduced reforms on the everyday experiences of Polish parents. Although it must be noted that since the analysis is mostly based on qualitative research, the results can indicate some deficiencies of the Polish family system, rather than draw conclusions on general and strong correlations. Therefore the analysis provided below should be treated as an invitation to further studies.

\section{BACKGROUND - POLISH FAMILY POLICY SYSTEM}

After the fall of communism most post-communist European states identified with the process of re-familialization and returned to more conservative family policies (Saxonberg 2014; Saxonberg \& Sirovátka 2006). Yet it seems that "Poland introduced a more liberal, implicitly genderizing variant than other countries" (Saxonberg 2014: 5), in which family policy was largely ignored in the 1990s and 2000s. The Polish parental leave system had been practically unchanged since 1974 and only in the 2000s were more significant amendments introduced (Saxonberg \& Szelewa 2007; Szelewa 2017). The system of public day care dramatically worsened in the 1990s because of the radical reduction of state aid to nurseries and kindergartens, as well as a neoliberal turn which transferred daycare institutions for children to the free market (Saxonberg 2014; Saxonberg \& Sirovátka 2006; Szelewa \& Polakowski 2008). One of the consequences of neglecting the family policy system was the dramatic drop in fertility rates in Poland and the problem of a rapidly ageing society. Dorota Szelewa (2017) describes the time after the collapse of communism as a period of implicit familialism 
in the Polish family policy. The process of privatization of care and the retrenchment of the family policy budget was accompanied by strengthening conservative attitudes to gender roles. Szelewa (2017) claims that since 2005 we can observe a turn towards explicit familialism, in which the family has become important on the political agenda. Yet the greatest focus on the family was not connected with a greater recognition of a problem of gender inequalities.

This article takes into consideration reforms introduced after 2010 in the context of their genderizing effects. Did they change the path of implicit genderization taken after 1989? During this period two political parties were in power. From 2007 to 2015 the government was composed of the liberal conservative Civic Platform (PO) and the agrarian Polish People's Party (PSL). The coalition was in power through two terms. In 2015 the national conservative Law and Justice Party (PiS) won the election and formed the new government. The PO/PSL government introduced three important reforms that substantially changed the family policy system; (1) the introduction of a two-week-long paternity leave and the extension of fathers' rights to take advantage of transferred maternity leave, (2) the introduction of a twenty-six week parental leave, and (3) the launch of the program "Toddler" for institutional care for children under three. Whereas, the succeeding PiS government introduced the program "Family 500+" - a child benefit (500 PLN per month). Undoubtedly, all of these new policies substantially changed the situation of Polish families, even though the policymakers' aims were not always realized.

\section{EXTENSION OF FATHERS' RIGHTS TO FAMILY-RELATED LEAVES}

In 2010 Polish men gained the right to two types of fully paid parental leave. In one piece of legislation a two-week paternity leave and additional transferred maternity leave (six weeks) were introduced. Beforehand paternity leave was one week long, in 2012 it was extended to two weeks, and it could only be used during the first year of a child's life (and from 2015 during the first two years). Additional maternity leave was also introduced in several steps - in 2010 and 2011 it was two weeks, in 2012 and 2013 four weeks and from 2014 it increased to six weeks. Before the reform, there was an obligatory fully paid twenty-week maternity leave. Having used fourteen weeks of leave, a mother could resign from the following six weeks only if a father used them. After maternity leave both parents had the right to a three-year child-rearing leave, which was means tested and restricted to those whose earnings were below the subsistence minimum. Thus the introduction of the additional maternity leave was a substantial help for both mothers and fathers, who could not afford to take unpaid child-rearing leave. The additional maternity leave was also described as a right of the father. The new legislation also sustained a rule introduced in 2001 according to which a father can use a part of the maternity leave (Florek 2015). Thus if a mother uses fourteen of her twenty weeks of maternity leave, then the remaining six weeks can be used by the father. When the six additional weeks of transferred maternity leave are taken into account, fathers gained rights to a total of twelve weeks transferred maternity leave. 
In the justification for the reform ${ }^{2}$ the introduction of paternity leave and men's right to additional transferred maternity leave are not mentioned at all (Serafin 2010). The aim of the additional maternity leave was to help women to combine paid work with motherhood. It is unclear why policymakers decided to introduce paternity leave and to give men the right to the transferred maternity leave - they do not mention these rights in the justification. One assumption is that they wanted to adjust the law to the EU directive of equal treatment of men and women, yet this directive did not impose an obligation of introducing paternity leave (Serafin 2010). The ambivalent attitudes of policymakers to paternity leave are also reflected in the statistics and by the lack of any dissemination strategy. There was no campaign organized to inform parents of the new possibilities. Until 2013 less than 10\% of eligible fathers decided to take the paternity leave. Only in 2014 did the statistics increase to over 30\% (see Table 1). ${ }^{3}$ It suggests that most parents did not see the merit in this leave. In the case of the right to a part of transferred maternity leave the lack of awareness was even greater. Some interviewees I talked to in 2013 reported that officials working in the Social Insurance Institution did not know that men had a right to transferred maternity leave. One of the interviewees had to prove to the institution that taking such leave was compliant with the law.

\begin{tabular}{|c|c|c|c|}
\hline & $\begin{array}{c}\text { fathers taking paternity } \\
\text { leave }\end{array}$ & number of children born & \% \\
\hline & in thousands & in thousands & \\
\hline $\mathbf{2 0 1 0}$ & 17,2 & 413,3 & 4,2 \\
\hline $\mathbf{2 0 1 2}$ & 28,6 & 386,2 & 7,4 \\
\hline $\mathbf{2 0 1 4}$ & 129,4 & 375,2 & 34,5 \\
\hline $\mathbf{2 0 1 6}$ & 146,4 & 382,3 & 38,3 \\
\hline $\mathbf{2 0 1 8}$ & 196,6 & 388,2 & 51,0 \\
\hline
\end{tabular}

Table 1. Polish fathers taking paternity leave

Source: Social Insurance Institution in Poland. Prepared by the author

Even though fathers are included in the introduced legislation, it is explicitly genderizing, since the role of a father is mainly perceived in terms of a helper or an additional caregiver, whose obligation is to support an overwhelmed mother or replace her when she cannot fulfill her role. The right of fathers to use paternity leave or transferred maternity leave is only optional, whereas women are obliged to take twenty weeks of maternity leave (or at least fourteen if the father takes the other six weeks).

\footnotetext{
${ }^{2}$ Justification. A legislative draft act amending the act - Labor Code and some other acts. Print No. 885 available at: http://orka.sejm.gov.pl/Druki6ka.nsf/0/605642C676BBAC75C12574B8004D197C/\$file/885-ustawa.doc [accessed June 20, 2018]

${ }^{3}$ It is not clear what the reasons for the increase are - it might be assumed in 2013 people became more aware of the existence of this leave, since the parental leave system was then more profoundly reformed by the introduction of gender-neutral parental leave (described below).
} 
The lack of reflection on gender roles and gender inequalities is visible in the justification of the reform, in which the problem of combining parenting with paid work is described as only a woman's issue. On the one hand, policymakers recognize the gender of individuals, but at the same time they just reproduce gender stereotypes and traditional parental roles. Men do not fit as the main recipients of family policy mechanisms.

\section{THE INTRODUCTION OF PARENTAL LEAVE ${ }^{4}$}

Parental leave as a right for mothers and fathers was introduced in 2013. Firstly, it was twenty-six-weeks and could be taken directly after having used twenty-six weeks of obligatory and additional maternity leave. In 2016 to simplify the system the additional maternity leave was merged with the paternity leave. Since then parents have a right to twenty weeks of obligatory maternity leave and thirty-two weeks of parental leave that is optional and can be freely shared (see Table 2). The new leave is highly paid - if parents decide to take fifty-two weeks of leave at the beginning, then the parent on leave receives benefits to the value of $80 \%$ of their salary. Whereas in the case of parents who choose to take twenty-six weeks of leave, they receive benefits to the value of $100 \%$. If parents decide later to take an additional twenty-six weeks, the benefit is $60 \%$.

\begin{tabular}{|c|c|c|}
\hline $\begin{array}{c}\text { Parental leave system till De- } \\
\text { cember } 2012\end{array}$ & $\begin{array}{c}\text { Parental leave system since } \\
\text { January } 2013\end{array}$ & $\begin{array}{l}\text { Parental leave system } \\
\text { since January } 2016\end{array}$ \\
\hline \multicolumn{3}{|c|}{ Maternity leave (obligatory for mothers, 6 weeks can be shared with a father) } \\
\hline $\begin{array}{l}20 \text { weeks ( } 14 \text { weeks only for } \\
\text { mothers) - benefit: } 100 \% \text { of sal- } \\
\text { ary }\end{array}$ & $\begin{array}{l}20 \text { weeks ( } 14 \text { weeks only for } \\
\text { mothers) - benefit: } 100 \% \text { or } 80 \% \\
\text { of salary }\end{array}$ & $\begin{array}{l}20 \text { weeks ( } 14 \text { weeks only for } \\
\text { mothers) - benefit: } 100 \% \text { of } \\
\text { salary }\end{array}$ \\
\hline \multicolumn{3}{|c|}{ Additional maternity leave (can be shared with a father) } \\
\hline 6 weeks - benefit: $100 \%$ of salary & $\begin{array}{l}6 \text { weeks - benefit: } 100 \% \text { or } 80 \% \\
\text { of salary }\end{array}$ & - \\
\hline \multicolumn{3}{|c|}{ Paternity leave (only for fathers) } \\
\hline 2 weeks - benefit: $100 \%$ of salary & 2 weeks - benefit: $100 \%$ of salary & $\begin{array}{l}2 \text { weeks - benefit: } 100 \% \text { of } \\
\text { salary }\end{array}$ \\
\hline \multicolumn{3}{|c|}{ Parental leave (can be shared by both parents) } \\
\hline- & $\begin{array}{l}26 \text { weeks - benefit: } 100 \% \text { or } 80 \% \\
\text { of salary }\end{array}$ & $\begin{array}{l}32 \text { weeks - benefit: } 100 \% \text { or } \\
80 \% \text { of salary }\end{array}$ \\
\hline \multicolumn{3}{|c|}{ Extended parental leave } \\
\hline $\begin{array}{l}36 \text { months - means-tested bene- } \\
\text { fit on low level }\end{array}$ & $\begin{array}{l}36 \text { months - means-tested bene- } \\
\text { fit on low level }\end{array}$ & $\begin{array}{l}36 \text { months - means-tested } \\
\text { benefit on low level }\end{array}$ \\
\hline
\end{tabular}

Table 2. Changes in the parental leave system

\footnotetext{
${ }^{4}$ The detailed description of the parental leave system in Poland can be found at the website of the International Network on Leave Policies and Research (https://www.leavenetwork.org/news/), where updated annual reports are published every year.
} 
In the justification for the reform ${ }^{5}$ the instrument is seen in terms of giving parents the opportunity to take care of a child during its first year of life and as a remedy for the problem of women leaving the workplace to take care of children. The latter argument is important in terms of gender inequality. The Polish system is characterized by a lack of congruency of leave and public childcare (Javornik \& Kurowska 2017). It means that after having used the paid leave, there is no guarantee that a place can be found for a child in a childcare institution. This gap between paid leave and childcare services is called here a childcare gap in a family system. The childcare gap is a huge problem for Polish parents - my interviewees emphasized that they had to find their own strategies to deal with childcare. The most common strategies for my interviewees were: women taking a few weeks of unpaid child-rearing leave, engaging grandmothers, hiring nannies (usually without a contract) or taking shifts at work. The introduced reform, together with the "Toddler" program described in detail below, to some extent is an answer to the problem of the care gap, yet it does not fully resolve it. The prolongation of paid leave only reduced the care gap, but did not eliminate it.

The new leave is described as more of a family right than an individual entitlement. Even though in their justification policy makers indicate that the new instrument would allow parents to share leave, there is no mention about gender roles and gender inequalities within the domestic sphere. Gender inequalities are only noticed in terms of women's participation in the labor market. There is no mention of men's engagement in domestic and care work. Consequently, the reform was introduced without any incentives for fathers. What is more, from the beginning parental leave was perceived as an extension of maternity leave and mostly as a new instrument addressed to women. Such attitudes were reflected, on the one hand, in the everyday language of many interviewees, in which parental leave was often called maternity leave, but also in the language of the law, which called the benefit received by a parent on parental leave a maternity benefit (in Polish: zasiłek macierzyński) (Kurowska 2013). Ironically, Polish politicians liked to compare the new parental leave scheme to the Swedish system, which is regarded in Poland as a very generous one which leads to high fertility rates. The issue of gender equality was completely ignored in this context together with the instrument of a father's quota which had been implemented in the Swedish system.

The official statistics show that there is a small number of men taking the leave (both in 2017 and 2018 only 1\% of all recipients are men - data from the Social Insurance Institution). The interviews conducted in 2017 also indicate that parents are not always aware that fathers have a right to parental leave. Some mothers openly said in the interviews that they were not eager to share their leave with their partners. Yet it does not mean that Polish society was not ready for a father's quota. There was also a huge group of parents who believed that such an instrument is needed and useful.

\footnotetext{
${ }^{5}$ Justification. Government bill amending the act - Labor Code and some other acts. Print No. 1310 available at: http://orka.sejm.gov.pl/Druki7ka.nsf/0/996E9241AE87223BC1257B5C0073225B/\%24File/1310-uzas.docx [accessed June 20, 2018].
} 
A: Ok, let's talk about parental leave.

B: Parental? Is there anything like that?

A:. Yes, there are six months of maternity leave and then six months of parental leave.

B: Oh, my wife stayed at home for a year. I thought it was maternity leave. (a partnered father with a $2 \frac{1}{2}$ year old child, 2017)

C: (...) [In 2013] I used only six months of the maternity leave because I was very focused on work and I did not want this experience of motherhood and I thought that my work is the most important thing in the world. But now, if I got pregnant now, if everything went well, I would definitely like to make the most of this time and I certainly would not start work early.

D: Ok, do you think you would like to share this leave with your husband?

C: I think I would regret giving it to him [my emphasis]. Because I mostly deal with housework, so I can make better use of this time, although if he said that he wanted to go on leave, I would definitely let him do it. (a partnered mother with a five year old child, 2017)

There is no reason why one of the genders should have a privileged position of having a right to parental leave. I think both parents should have an opportunity to go on leave. (a partnered father with a two year old, 2012)

The new instrument of parental leave is explicitly genderizing. Even though the instrument is described as an entitlement for mothers and fathers, it is used predominantly by women. What is more, since parental leave is perceived as an extension of maternity leave, the entitlement is seen as a woman's right that in some exceptional circumstances can be shared with the father. Consequently, the current parental leave system in Poland offers time and money mainly to women to look after their children. Even though men have started to be included in the system as recipients of leave, their marginal role in the domestic sphere is reinforced by the cultural norms about care. The potential of the reforms to change gender roles in the domestic sphere was not achieved, this is because of the decision not to introduce more interventionist instruments such as a father's quota.

\section{THE “TODDLER” PROGRAM - CHILDCARE INSTITUTIONS FOR CHILDREN UNDER THREE}

In 2011 the Ministry of Labor and Social Policy launched the "Toddler" program, which is a long-term program to increase the number of places in childcare institutions for children under three, and introduced such institutions as: nurseries, “children's clubs”, 
"daily caregivers" and "nannies". The reform is aimed at resolving the problem of a childcare gap in Poland. The program is still running and its yearly budget is increasing - when it was launched in 2011 the budget was 40 million PLN, in 2013 it increased to 100 million PLN, in 2015 to 151 million PLN, and in 2018 the planned budget is 450 million PLN. It was also introduced in connection to the EU requirement set in the Barcelona Strategy related to services for children - 33\% of children under three should have guaranteed places in childcare institutions by 2010 (European Commission 2002, 2013). The program has also led to legislative changes that simplified very demanding requirements to run a nursery (prior to the reform, nurseries were treated as healthcare institutions, see: Saxonberg 2014).

In the justification for the reform ${ }^{6}$ policymakers underlined the increasing problem of the work-life balance faced by women today. The articulated aims were as follows: (1) to promote women's activity in the labor market and consequently improve the financial situation of Polish families and gender equality; (2) to support Polish families with procreation plans and with raising children; (3) to guarantee access to education for all children. As is the case with previously analyzed reforms, there was no mention of the role of men in the private sphere. Even though the problem of gender inequality was recognized in the justification, Saxonberg (2014) suggests that the motivation for doing so was compliance with EU gender mainstreaming policy. Saxonberg's analysis of the role played by the EU in terms of gender equality policies in Central European countries, demonstrates that many anti-discrimination laws in Central Europe were introduced only because they were an EU requirement. What is more, in the analyzed justification gender inequality was only acknowledged in the labor market. Once again there was no mention of gender inequalities within the domestic sphere.

The reform has resulted in a slight improvement in access to daycare institutions for children under three - from 2008-2017 the number of children attending daycare increased from 2.6-8.6\% (see Table 3). Although the situation is still unsatisfactory Poland is still characterized by one of the lowest enrollment rates in comparison with other EU countries. There is a genuine need for this program, as was confirmed in the interviews, yet it is being implemented too slowly. Large geographical disparities still exist between cities and rural areas - according to the Statistics Poland in 2017 children under three who attended a daycare institution amounted to $13.3 \%$ in cities but only $2 \%$ in rural areas.

\begin{tabular}{|c|c|c|c|c|c|c|}
\hline & $\mathbf{2 0 0 8}$ & $\mathbf{2 0 1 0}$ & $\mathbf{2 0 1 2}$ & $\mathbf{2 0 1 5}$ & $\mathbf{2 0 1 7}$ & $\mathbf{2 0 1 9}$ \\
\hline 0-3 years & 2,6 & 2,6 & 3,8 & 6,8 & 8,6 & 12,4 \\
\hline 3-5 years & 52,7 & 62,6 & 69,7 & 84,2 & 84,7 & 88,5 \\
\hline
\end{tabular}

Table 3. Percentage of children enrolled in day care institutions

Source: Statistics Poland. Prepared by the author.

\footnotetext{
${ }^{6}$ Foundations for the act on care forms for children under 3 years old available at: https://www.mpips. gov.pl/gfx/mpips/.../zalozenia\%20zlobki\%2015.07.2010.doc [accessed June 20, 2018].
} 
One of the outcomes of the reform is the process of marketization, since both public and private childcare institutions can receive funding. Consequently, the private institutions account for $63 \%$ of all institutions. It is not clear what will happen to them when the program stops - there is a possibility that the cost of childcare will raise.

It could be argued that the program promotes degenderization since the state overtakes a part of the care obligations of women. Yet taking into account its limited effect, it is clear that the "Toddler" program did not substantially change the policy orientation. Even so, in the context of gender inequalities, this reform should be seen as an improvement for the situation of women in the labor market, but in the context of the family sphere the situation looks different. The aim of the program is to support families, yet the program in fact supports women in their caring obligations and as such does not change the gender order. Together with the parental leave scheme oriented on mothers, the system does not reconstruct the role of the father. Men are still seen in terms of breadwinners and additional caregivers, who need to support mothers, but who are not primarily obliged to provide care work (see: Pustułka, Struzik \& Ślusarczyk 2015; Suwada 2021). Comparing the percentage of children enrolled in childcare institutions, it is clear that there is still a huge gap between children under and over three. It means that women are still expected to resign from or limit their paid work for the sake of motherhood for the first three years. The gender-neutral language of the reform results in explicit genderization.

The interviews also support the assumption that childcare institutions are perceived as an instrument to help women in combining work with motherhood. Parents often emphasize that there is a need for greater support from the state in terms of childcare institutions. The main reason for such a need is help for women expressed by mothers and fathers. Men never mention the potential benefits for them from such support, probably because they are never expected to leave the labor market because of the lack of places in nurseries.

I believe the state should provide access to daycare institutions for all children. You know, making these institutions near to a workplace... Maybe companies should build nurseries and kindergartens? To have somewhere near to a workplace. I think it should be the standard. It would be very helpful for mothers (a partnered mother with a seven year old child, 2017)

Why can't I have access to a nursery ... get a place in a nursery? This is a part of the family policy, isn't it? At this moment the best option would be ... if my wife gave up her work [my emphasis] and took care of our child. It is profoundly sad that there are not enough places in nurseries. (a partnered father with a four month old baby, 2013)

\section{THE “FAMILY 500+” PROGRAM}

The "Family 500+" program is the flagship program of the governing Law and Justice party, which they introduced in April 2016. It offers a monthly cash benefit (500 PLN, approx. 110 EUR in November 2021) for every second and subsequent child regardless 
of the family's financial situation. Initially for families with only one child the benefit was means tested, since July 2019 it has beed granted to every child in the family until they are 18 years old. The scope and budget of the program is an exception in the Polish welfare state. In 2017 and 2018 the annual cost of the program was around 22 billion PLN (it is almost fifty times more than the budget for the "Toddler" program in 2018). In 2019 it raised to 30,5 billion PLN. In 20172.5 million families were entitled to receive the benefit (3,7 million of children). In 2019 the number of children raised to 6 million children ${ }^{7}$. The current government describes the program as a systemic and critical instrument of family policy that is a solution to the demographic crisis. This crisis results, according to the government, from the bad economic situation of young people, who decide not to have more than one child and to emigrate. So the aim of the program is not only to encourage Poles to have more children, but also to encourage them to stay in Poland, or even return from abroad. The second aim of the program is to combat child poverty. ${ }^{8,9}$

The program gave rise to multiple controversies from different political sides. A monthly tax-free 500 PLN subvention is a considerable amount of money, keeping in mind the fact that the median monthly income in Poland in October 2016 was around 3,500 PLN before taxes (approx. 2,500 PLN after taxes) and the most common income was around 2,100 PLN before taxes (approx.1,500 PLN after taxes) (Statistics Poland 2018). Analysis of the interviews from 2017 indicates that part of the Polish middle class parents tend to assess the program negatively based on stereotypes of poor parents with big families who spend money on alcohol and things not devoted for children. Other middle class parents perceive it as a necessary redistribution mechanism, which hopefully reduces income inequalities. For lower class families the benefit is regarded as much needed help. None of the interviewees thought that it could actually encourage people to have more children. The same concerns are expressed by experts who underlines that so far the program has no significant effect on fertility rates (Karwacki \& Szlendak 2021; Magda et al. 2019).

In the context of gender inequalities when the program was introduced, some critics are afraid that it will encourage women to leave the labor market for motherhood (Karwacki \& Szlendak 2021). And in fact such effect was observed by the experts, who estimated that during the first year from the introduction of the program around 91103 thousands women with one or two children withdrew from the labor market. This mostly applies to women with lower level of educations and living in smaller cities (Magda et al. 2019). Since women in Poland earn less than men (Statistics Poland

\footnotetext{
${ }^{7}$ Data from Statistics Poland, available at: https://bdl.stat.gov.pl/BDL/start [accessed January 20, 2021]. 8 Justification. Government bill on state aid in raising children available at: http://orka.sejm.gov.pl/Druki8ka.nsf/0/6A2B97FB4F15F393C1257F4D002A61A2/\%24File/216-uzasadnienie.doc [accessed June 20, 2018].

${ }^{9}$ Speech by Elżbieta Rafalska, Minister of Family, Labor and Social Policy at the first reading of the government draft law on state aid in raising children on 9 February 2016 available at: https://www.mpips. gov.pl/wsparcie-dla-rodzin-z-dziecmi/rodzina-500-plus/dokumenty-i-opracowania/wystapienie-elzbiety-rafalskiej-minister-rodziny-pracy-i-polityki-spolecznej-podczas-pierwszego-czytania-rzadowego-projektu-ustawy-o-pomocy-panstwa-w-wychowywaniu-dzieci-/ [accessed June 20, 2018]
} 
2018), the program can be described as gender-blind, because it does not recognize the potential effects on labor market participation of men and women. As such the mechanism has a genderizing effect especially on lower class families. This assumption was also confirmed in the interviews with lower class parents, in which it was often emphasized that the benefit 500+ when combined with other benefits, equaled the minimum wage. If this wage is earned by physically demanding work, for example in a factory with exhausting working hours, the decision to leave the labor market at least for a few years is easy. Additionally, in the countryside and small towns, there is often a greater problem with access to a daycare institution, which is an additional factor pushing women out of the labor market.

And there is this 500+ now and I have more money than when I worked. Additionally, if I go back to work, I will have to wake up at 4 am because I have a bus at $5.20 \mathrm{am}$. We have three shifts at work, but I would not work at night because of the children, right? And this is hard to deal with. I have a friend who has a child of the same age, but she has a grandmother to help, so she can go to work, but me? No, it is impossible... It is difficult. (a partnered mother with two children, aged two and five, 2017)

\section{GENDERIZING CONSEQUENCES OF THE REFORMS}

The discussed reforms significantly improved the situation for the parents of young children. This is especially so concerning the changes in the parental leave scheme prolonging highly paid parental leave from twenty to fifty-two weeks, and also for the "Toddler" program, both of which had an impact on the everyday life of parents (particularly in big cities). In 2012 and 2013 interviews were conducted with parents who had no opportunity to profit from the new instruments - all of the women who were interviewed had the right to a twenty or twenty-six week maternity leave, and some of the men had the right to one or two weeks of paternity leave. Many of them had unsuccessfully been looking for a place in a nursery for their children aged under three, but were forced to engage grandparents (mostly grandmothers), hire nannies, or find different ways to organize care for their children. In interviews carried out in 2017 there was more satisfaction from the parental leave scheme, especially from parents who had their first child before 2013, and their second or subsequent child after the introduction of parental leave. What is more, in comparison with interviews conducted in 2013, parents in 2017 did not think that the period of leave should be prolonged. They mostly thought that fifty-two weeks is a proper length of time for maternity and parental leave. Yet there is still a problem with finding a place in a childcare institution for children under three, though middle class parents from big cities are facing fewer difficulties in 2017 than in 2013. Also the "Family 500+" program is mostly described as a great financial help, especially by parents with lower incomes.

In terms of gender inequalities the reforms did not propose the reconstruction of gender order. In fact none of them recognized the issue of gender inequalities, because all of them treat the family policy instruments as family-based entitlements rather 
than individual ones. A mother and a father have a joint right to thirty-two weeks of leave, and a joint right to 500+ benefit. According to policymakers they should choose how they want to share it. Even though men were included in the parental leave scheme and women's unfavorable situation in the labor market was recognized in the official documents, policymakers still see the family as a unit and design instruments for a whole family, not an individual parent. What is more, Polish policymakers recognize the problem of gender inequalities in a narrow perspective, in which only a woman's position in the labor market is acknowledged. Such a perspective ignores the fact that gender inequalities are of structural character and inequalities in different spheres of social reality are interconnected. Women's disadvantaged position in the labor market is related to their domestic and care obligations. Based on gender beliefs (Ridgeway \& Correll 2004) men are not expected to participate in this unpaid work to the same extent. And in Poland indeed they do not - in 2013 an average partnered man with children aged 0 - 17 years spent half the time on household and family care duties ( 3 hrs 2 mins per day) than an average partnered woman (6 hrs 46 mins per day) (Statistics Poland 2016). Consequently, women's double burden hinders their participation in the labor market - being overwhelmed at home can make women less engaged in their paid work. By ignoring men's privileged position in the domestic sphere, policymakers are not able to design a policy system reducing gender inequalities in the public sphere.

On the one hand, it could be argued that the first step was taken in the direction of making men more involved in family life by giving them the right to transferred maternity leave in 2010, and then to parental leave in 2013. Yet it was not the intention of these reforms. In fact, it is not clear why policymakers decided to give men rights to parental leave. It might have been that the aim was to make it easier for men to use the leave in some exceptional situations, in which women could not fulfill care and domestic obligations. Even if we assume that the aim was to make fathers more engaged in the domestic sphere, their role is still seen in terms of an additional caregiver. A man's right to parental leave is not enough. It is confirmed by the experiences of the Nordic countries, which show that such a right granted a few decades ago did not make men automatically more involved in family life (Kaufman \& Almqvist 2017; Lundqvist 2011). Even though Polish fathers have a right to parental leave, they do not use it. It suggests that granting men the right to parental leave without so called 'fathers quotas' basically makes their position even more privileged, since they gain the right to choose to what extent they want to be involved in taking care of their children.

The reforms did not improve women's situation in the labor market. The studies show that their position is still not equal to men's. Women still earn less, more often work part-time, have longer breaks from employment because of parenthood, are less often promoted, and their participation in the labor market is more often perceived in terms of economic necessity rather than pursuing a career (Kotowska et al. 2008; Suwada 2021). Also the introduced reforms show that the aim is not to make women's position in the labor market equal to men's, but rather to help women to achieve a work-life balance by prolonging parental leaves, encouraging men to be more engaged secondary caregivers, and assisting in care by creating more places in day care institu- 
tions or giving a cash benefit. None of the analyzed reforms challenged the gendered parental roles as such. They have explicitly genderizing consequences in accordance with the assumption that women have a personal obligation for care and domestic work, and that the role of the state is to support them in it.

\section{CONCLUSION}

Low fertility rates are an urgent problem for the Polish welfare state. For the last few decades they have never exceeded the level of 1.5. Thus in the near future Poland will be dealing with the consequences of an ageing society. It is in the interest of the welfare state to prevent at least some of these consequences by reversing the current demographic trend. It is commonly assumed that one way to do so is to design a family policy system that allows parents to combine family life with participation in the labor market. This assumption is based on a premise that labor market conditions are unfriendly for parents, especially mothers. Then the aim of the family policy is to reduce the tensions between labor market requirements and family life and also to protect parents. There is still a problem of ignoring the gender dimension in such thinking. The experiences of some European countries indicate that fertility rates are connected with the level of gender inequalities in a society (Duvander \& Andersson 2006; Lappegård, Rønsen, \& Skrede 2011). Irena Kotowska et. al. (2008: 843) notes that policies that diminish differences between gender roles and promote gender equality strengthen the reconciliation mechanisms of the policy system by reducing the incompatibility between work and family requirements for men and women. Yet other research shows inconclusive results on links between fertility and gender equality (Billingsley \& Ferrarini 2014; Neyer, Lappegård, \& Vignoli 2013).

What is the situation in Polish society? Does gender inequality affect people's reproductive behavior? Following the reasoning of Neyer, Lappegård and Vignoli (2013), I understand here gender equality as a situation in which there is fairness and social justice between men and women. So the concept is not about the sameness of men and women, but equal opportunities to participate in different areas of social life. Neyer, Lappegård and Vignoli (2013) indicate that to understand the links between gender equality and fertility there is a need to distinguished between gender equality in family-oriented institutions and gender equality in individual-oriented institutions. The incongruent development of gender equality in these two areas leads to low fertility in society. This might be true of Poland. In the Polish context we can observe quite high gender equality in individual-oriented institutions such as the labor market or education. Polish society is an example of a society in which women's participation in the labor market and in education is unquestioned. Even though women are often perceived as a secondary labor force (Kotowska et al. 2008), they are better educated than men and expect to contribute to household income. On the other hand, there is low gender equality in family-oriented institutions in which women carry a double burden and spend much more time on unpaid work in the domestic sphere than men.

Before the reforms of the 2010s the system was implicitly genderizing because of its market-orientation and a general negligence of family policy. The introduction of the 
reforms changed the system into an explicitly genderizing one. Most of the reforms are based on the assumption that the main obligations within the family sphere belong to women. There has been a slight change in the perception of the father's role, not only in terms of being the main breadwinner, but also in terms of an additional caregiver, yet this change is not connected with the reconstruction of the gender order. The described reforms were introduced as an answer to the problem of low fertility rates. Yet even though policymakers recognize that low fertility results to some extent from women's increasing problem of combining work with motherhood, they totally neglected the issue of gender inequalities within the domestic sphere. This shows that Polish politicians still treat the family policy system as a tool for raising fertility rates (Korsvik and Warat 2016) rather than as an interventionist mechanism reducing gender inequalities (Kurowska et al. 2016). This begs the question whether it is possible to reverse the demographic trends without a shift in thinking about gender inequalities by Polish policymakers. Current fertility rates and the experiences of other countries raise serious doubts as to whether there will be a positive outcome.

FUNDING: The research was financed by the National Science Centre of Poland, grant Sonata 10 no UMO- 2015/19/D/HS6/02338.

CONFLICT OF INTEREST: The author declares no conflict of interest.

\section{REFERENCES}

Andersson, Gunnar, Ann-Zofie Duvander, \& Karsten Hank. 2004. “Do Child-Care Characteristics Influence Continued Child Bearing in Sweden? An Investigation of the Quantity, Quality, and Price Dimension.” Journal of European Social Policy 14(4):407-18. doi: 10.1177/0958928704046881.

Ayres, Lioness. 2008. “Thematic Coding and Analysis.” Pp. 867-68 in The SAGE Encyclopedia of Qualitative Research Methods, edited by L. M. Given. Los Angeles, Calif: Sage Publications.

Benaquisto, Lucia. 2008. “Code and Coding.” Pp. 85-88 in The SAGE Encyclopedia of Qualitative Research Methods, edited by L. M. Given. Los Angeles, Calif: Sage Publications.

Billingsley, Sunnee \& Tommy Ferrarini. 2014. "Family Policy and Fertility Intentions in 21 European Countries: Family Policy and Fertility Intentions.” Journal of Marriage and Family 76(2):428-45. doi: 10.1111/jomf.12097.

Duvander, Ann-Zofie \& Gunnar Andersson. 2006. “Gender Equality and Fertility in Sweden.” Marriage \& Family Review 39(1-2):121-42.doi: 10.1300/J002v39n01_07. European Commission. 2002. “Presidency Conclusions.” Barcelona European Council. European Commission. 2013. Barcelona Objectives: The Development of Childcare Facilities for Young Children in Europe with a View to Sustainable and Inclusive Growth. 
Luxembourg: European Union.

Florek, Ludwik. 2015. “Ewolucja Kodeksu Pracy.” Studia Iuridica Lublinensia 24(3):29. doi: 10.17951/sil.2015.24.3.29.

Graff, Agnieszka. 2014. Matka Feministka. Warsaw: Wydawnictwo Krytyki Politycznej. Javornik, Jana \& Anna Kurowska. 2017. "Work and Care Opportunities under Different Parental Leave Systems: Gender and Class Inequalities in Northern Europe." Social Policy \& Administration 51(4):617-37. doi: 10.1111/spol.12316.

Karwacki, Arkadiusz \& Tomasz Szlendak. 2021. "Fulfilled Promise or a Tool of Political Rhetoric? Analysis of the Consequences of the Polish '500+ Family' Program.” Problemy Polityki Społecznej. Studia i Dyskusje 51:75-98. doi: 10.31971/ pps/131160.

Kaufman, Gayle \& Anna-Lena Almqvist. 2017. "The Role of Partners and Workplaces in British and Swedish Men's Parental Leave Decisions.” Men and Masculinities 20(5):533-51. doi: 10.1177/1097184X17727570.

Korolczuk, Elżbieta \& Renata E. Hryciuk. 2012. „Wstęp pożegnanie z Matką Polką?” Pp. 7-24 in Pożegnanie z Matka Polką? Dyskursy, praktyki i reprezentacje macierzyństwa we współczesnej Polsce, edited by E. Korolczuk \& R. E. Hryciuk. Warsaw: Wydawnictwo Uniwersytetu Warszawskiego.

Korsvik, Trine Rogg \& Marta Warat. 2016. "Framing Leave for Fathers in Norway and Poland: Just a Matter of Gender Equality?” NORA - Nordic Journal of Feminist and Gender Research 24:110-25. doi: 10.1080/08038740.2016.1182588.

Kotowska, Irena, Janina Józwiak, Anna Matysiak, \& Anna Baranowska. 2008. "Poland: Fertility Decline as a Response to Profound Societal and Labour Market Changes?” Demographic Research 19:795-854. doi: 10.4054/DemRes.2008.19.22.

Kurowska, Anna. 2013. „Ocena Zasadności Założeń Reformy Urlopów i Zasiłków Związanych z Opieką Nad Małym Dzieckiem.” Problemy Polityki Społecznej $2(21): 155-70$.

Kurowska, Anna. 2018. “(De)Familialization and (De)Genderization - Competing or Complementary Perspectives in Comparative Policy Analysis?” Social Policy \& Administration 52(1):29-49. doi: 10.1111/spol.12272.

Kurowska, Anna, Bartosz Pieliński, Ryszard Szarfenberg, \& Anna Wójtewicz. 2016. Perspektywa gender $w$ polityce społecznej. Torun: Wydawnictwo Naukowe Uniwersytetu Mikołaja Kopernika.

Lappegård, Trude, Marit Rønsen, \& Kari Skrede. 2011. "Fatherhood and Fertility.” Fathering: A Journal of Theory, Research, and Practice about Men as Fathers 9(1):10320. doi: 10.3149/fth.0901.103.

Lundqvist, Åsa. 2011. Family Policy Paradoxes: Gender Equality and Labour Market Regulation in Sweden, 1930-2010. Bristol: Policy Press.

Magda, Iga, Michał Brzeziński, Agnieszka Chłoń-Domińczak, Irena Kotowska, Michał Myck, Mateusz Najsztub, \& Joanna Tyrowisz. 2019. 'Rodzina 500+' - Ocena Programu i Propozycje Zmian. Warsaw: Instytut Badań Strukturalnych.

Mynarska, Monika. 2011. „Kto Planuje Mieć Dzieci w Polsce Do 2015 Roku?” Studia Demograficzne 159(1):75-98.

Neyer, Gerda, Trude Lappegård, \& Daniele Vignoli. 2013. “Gender Equality and Fertil- 
ity: Which Equality Matters?" European Journal of Population / Revue Européenne de Démographie 29(3):245-72. doi: 10.1007/s10680-013-9292-7.

Pustułka, Paula, Justyna Struzik, \& Magdalena Ślusarczyk. 2015. “Caught between breadwinning and emotional provisions-The case of Polish migrant fathers in Norway." Studia Humanistyczne AGH 14(2): 117. https://doi.org/10.7494/human.2015.14.2.117.

Ridgeway, Cecilia L. \& Shelley J. Correll. 2004. "Unpacking the Gender System a Theoretical Perspective on Gender Beliefs and Social Relations." Gender \& Society 18(4):510-31. doi: 10.1177/0891243204265269.

Rothbauer, Paulette M. 2008. "Triangulation." Pp. 893-94 in The SAGE Encyclopedia of Qualitative Research Methods, edited by L. M. Given. Los Angeles, Calif: Sage Publications.

Saxonberg, Steven. 2013. "From Defamilialization to Degenderization: Toward a New Welfare Typology.” Social Policy \& Administration 47(1):26-49. doi: 10.1111/j.1467-9515.2012.00836.x.

Saxonberg, Steven. 2014. Gendering Family Policies in Post-Communist Europe: A Historical-Institutional Analysis. Basingstoke: Palgrave Macmillan.

Saxonberg, Steven \& Tomáš Sirovátka. 2006. "Failing Family Policy in Post-Communist Central Europe." Journal of Comparative Policy Analysis: Research and Practice 8(2):185-202. doi: 10.1080/13876980600682089.

Saxonberg, Steven \& Dorota Szelewa. 2007. "The Continuing Legacy of the Communist Legacy? The Development of Family Policies in Poland and the Czech Republic." Social Politics: International Studies in Gender, State \& Society 14(3):351-79. doi: 10.1093/sp/jxm014.

Scambor, Elli, Nadia Bergmann, Katarzyna Wojnicka, Sophia Belghiti-Mahut, Jeff Hearn, Øystein Gullvåg Holter, Marc Gärtner, Majda Hrženjak, Christian Scambor, \& Allan White. 2014. "Men and Gender Equality: European Insights." Men and Masculinities 17(5):552-77. doi: 10.1177/1097184X14558239.

Serafin, Katarzyna. 2010. „Prawo Do Urlopu Ojcowskiego w Polskiej Regulacji Prawne.” Zeszyty Prawnicze UKSW (10.1):221-32.

Statistics Poland. 2016. Budżet Czasu Ludności 2013. Część II [Time Use Survey 2013. Part 2]. Warsaw.

Statistics Poland. 2018. Structure of Wages and Salaries by Occupations in October 2016. Warszawa: Statistics Poland. Demographic Surveys and Labour Market Department.

Suwada, Katarzyna. 2017. Men, Fathering and the Gender Trap. Sweden and Poland Compared. Basingstoke: Palgrave Macmillan.

Suwada, Katarzyna. 2021. Parenting and Work in Poland: A Gender Studies Perspective. Cham: Springer International Publishing.

Szelewa, Dorota. 2017. “From Implicit to Explicit Familialism: Post-1989 Family Policy Reforms in Poland.” Pp. 129-51 in Gender and Family in European Economic Policy. Cham: Palgrave Macmillan.

Szelewa, Dorota \& Michal P. Polakowski. 2008. "Who Cares? Changing Patterns of Childcare in Central and Eastern Europe." Journal of European Social Policy 
18(2):115-31. doi: 10.1177/0958928707087589.

\section{BIOGRAPHICAL NOTE}

Katarzyna Suwada is Assistant Professor at the Institute of Sociology, Nicolaus Copernicus University in Torun, Poland. Her research interests include fatherhood, motherhood, gender inequalities in family life, family policy.

OPEN ACCESS: This article is distributed under the terms of the Creative Commons Attribution Non-commercial License (CC BY-NC 4.0) which permits any non-commercial use, and reproduction in any medium, provided the original author(s) and source are credited.

ARTICLE HISTORY: Received 2021-03-11 / Accepted 2021-11-23 